\title{
Monitoring of the structure and distribution of periodontal disease in children of the Donetsk region according the applay
}

\author{
S. P. Yarova, K. V. Novikova*, O. Y. Chernyshova, O. M. Novikova, O. A. Kobtseva \\ Donetsk National Medical University \\ *Correspoding author. E-mail: katyanovik93@gmail.com
}

Paper received 18.06.18; Accepted for publication 26.06.18.

\section{https://doi.org/10.31174/SEND-NT2018-172VI20-11}

\begin{abstract}
The aim of the research was to study the structure of periodontal pathology in children in Donetsk region who applied for periodontal care in three age groups (3-6 years, 7-12 years, 15-18 years). Clinically 207 children were examined. The presence of periodontitis was found in all age groups in 34 of 207 subjects $(16.4 \%)$. It was found that the main cause of treatment of children $(83.6 \%, 173 / 207)$ of all age groups is the presence of gingivitis $-95.2 \%, 93.1 \%, 56.9 \%$, respectively.
\end{abstract}

Keywords: monitoring, gingivitis, periodontal disease.

Introduction. Last decades were marked by significant achievements in the field of studying children's periodontal diseases and oral mucosa. The initiative form of the work of the pediatric dentist, whose task is to maximize the coverage of the entire children's population with the attention of the dentist, with the purpose of early detection of pathology, timely elimination of the disease and its prevention, was expressed by the fact of appearance of children who did not expect the presence of such diseases as gingivitis and periodontitis.

Overview of publications on the topic. Insufficient attention to the timely detection and elimination of diseases of the mucous membrane of the oral cavity and periodontium in children promotes an increase in the frequency and severity of periodontal diseases in adults [1].

At the same time, there appeared a sufficient number of scientific reports revealing the essence of the pathogenesis of diseases of the mucous membrane of the oral cavity and periodontium in children with their conjugation with tooth caries, poor hygienic state of the oral cavity, and dental alveolar anomalies.

In accordance with modern ideas, the formation of inflammatory periodontal diseases is considered not only as a local inflammation of the periodontal tissue caused by the microflora of the "dental plaque", but also as a reaction of the organism to a bacterial infection [2].

Nowadays most of the known researchers recognize that only the balance between local resistance of the oral cavity and bacterial invasion is the main factor that determines the development and course of lesions of periodontal tissue $[3,4,5,6]$. As a result of damage, activation or release of some biologically active substances that largely determine the rate of development, intensity and prevalence of the inflammatory process occurs [1]. Microbial dental plaque and products of its vital activity are an important link in the chain of factors that cause inflammation and destructive changes in periodontal tissues [7].

It is important to remember that the condition of periodontal tissues of children, regardless of their age group, differs from that already formed in an adult.

Purpose of the study: studying of the prevalence and structure of periodontal diseases in children of different ages who live in the Donetsk region, as well as indicators of their treatment for the treatment of periodontal diseases and oral mucosa.
Materials and methods. To realize the goal of the study, the parodontological status of 207 children of the Donetsk region was analyzed, who applied for consultative periodontal care at the Department of Stomatology № 2 of the Donetsk National Medical University from 2016 to 2017. Taking into account WHO recommendations, the structure and prevalence of parodontological pathology was monitored in three age groups: group 1 included 63 children 3-6 years old (milk bite); group 2 consisted of 86 people aged 7-12 years (the period of the replaceable occlusion) and in group 3, 58 children - 13-18 years (permanent bite).

1 group consisted of 63 people, the total number of children 2 and 3 groups - 86 and 58 children, respectively. According to the results of the survey, each study group was divided into 2 subgroups. Subgroups A of groups 1, 2, 3 included children with gingivitis (catarrhal or hypertrophic), subgroup B-manifestation of periodontitis (localized or generalized) (Table 1).

Table 1.

\begin{tabular}{|c|c|c|}
\hline Group number & $\begin{array}{c}\text { Number of children } \\
\text { in subgroup A }\end{array}$ & $\begin{array}{c}\text { Number of children } \\
\text { in subgroup B }\end{array}$ \\
\hline Group 1 $(\mathrm{N}=63)$ & 60 & 3 \\
\hline Group 2 $(\mathrm{N}=86)$ & 80 & 6 \\
\hline Group 3 $(\mathrm{N}=58)$ & 33 & 25 \\
\hline Total $(\mathrm{N}=207)$ & 173 & 34 \\
\hline
\end{tabular}

The examination of children was carried out according to the standard method in dentistry, which included the collection of complaints, anamnesis of life and disease, external examination of the child and examination of the oral cavity, determined the Green-Vermilion and PMA indices, performed the Schiller-Pisarev test, and measured the depth of the dentogingival pockets. The materials of the clinical study were subjected to variational-statistical treatment in accordance with the purpose of the work. The processing of the results of the study was carried out using the generally accepted methods of mathematical statistics.

Results and discussion. The reason for seeking dental care most patients called the presence of bleeding gums during brushing, its soreness, friability. Some of them independently noted congestion, mucous puffiness and a bad smell. Also, there were complaints such as: gum enlargement or gingival abscess.

Analysis of the periodontological status of patients who consulted for medical advice showed that the pres- 
ence of gingivitis was $83.6 \%(173 / 207)$ of the children, periodontitis was detected in $16.4 \%$ of the children surveyed. Particular attention was drawn to the fact that there was a significant spread of catarrhal localized gingivitis (49\%, 102/207) (Table 2).

Table 2.The prevalence of periodontological pathology among the children under examination

\begin{tabular}{|c|c|c|c|c|}
\hline \multirow{2}{*}{ Type of pathology } & \multicolumn{4}{|c|}{ Frequency of distribution } \\
\hline & & & & \\
\hline Catarrhal gingivitis (localized) & \multirow{6}{*}{207} & 102 & \multirow{6}{*}{100} & 49 \\
\hline Catarrhal gingivitis (generalized) & & 31 & & 15 \\
\hline Hypertrophic gingivitis (localized) & & 31 & & 15 \\
\hline Catarrhal gingivitis (generalized) & & 9 & & 4,3 \\
\hline Periodontitis (localized) & & 25 & & 12 \\
\hline Periodontitis (generalized) & & 9 & & 4,3 \\
\hline
\end{tabular}

The results of the study of the structure and distribution of periodontal pathology among the children of Donetsk region examined by age group showed that the highest exponent of spread in all age groups had localized catarrhal gingivitis $(63.4 \%, 58.1 \%, 20.7 \%)$. In our opinion, this can be explained by increased traumatic danger in childhood, unsatisfactory oral hygiene, dental alveolar anomalies. Also the great importance is the psychoemotional status of the child, the presence of harmful habits with the help of which the child calms himself.

Analysis of the study parameters by age group showed that the children of the 1st age group had the following results: out of 63 children, $77.7 \%$ (49/63) had catarrhal gingivitis, $18.5 \%(9 / 49)$ of the patients had catarrhal generalized, 81, 5\% (40/49) respectively localized. At the same time, $17.5 \%(11 / 63)$ had localized hypertrophic gingivitis, while general hypertrophic gingivitis was not found in this group. The remaining 4.8\% (3/63) already had localized periodontitis due to dentoalveolar anomalies. There were no generalized forms of periodontitis.

Representatives of the 2nd group had the following indicators: out of 86 examined, $73.3 \%$ (63/86) had catarrhal gingivitis, $20.6 \%(13 / 63)$ were diagnosed with generalized catarrhal gingivitis, $79.4 \%(50 / 63)$ were ill with localized form. Concerning hypertrophic gingivitis, $19.8 \%$ (17/86) had symptoms of this disease: $41.2 \%$ (7/17) had a generalized form of this pathology, and $58.8 \%(10 / 17)$, localized. In the remaining $6.9 \%(6 / 86)$, localized periodontitis was detected. As with the representatives of the first group of generalized forms of periodontitis was not revealed.

The examination of children of the 3rd age group showed the following results: out of 58 people, $36.2 \%$ $(21 / 58)$ had catarrhal gingivitis, $42.9 \%(9 / 21)$ generalized form, $57.1 \%(12 / 21)$ localized. $20.7 \%$ (12/58) had signs of hypertrophic gingivitis, $16.7 \%(2 / 12)$ of the generalized, $83.3 \%(10 / 12)$ of the localized. The remaining $43.1 \%(25 / 58)$ have already revealed a feature of periodontitis: $64 \%(16 / 25)$ had a localized form, while $36 \%$ $(9 / 25)$ have already had a generalized form of periodontitis.

Conclusions. The main reason for the treatment of children of all age groups for periodontal care is the presence of problems with the state of the mucosa of the oral cavity and periodontium. In the structure of periodontal pathology, gingivitis predominates more than periodontitis. The most common pathology is localized catarrhal gingivitis $49.3 \%(102 / 207)$ of the total number of children. Often there are generalized catarrhal 15\% (31/207) and localized hypertrophic gingivitis. There are cases of generalized periodontitis in $4.3 \%(9 / 207)$ of all the children studied.

\section{ЛИТЕРАТУРА}

1. Воложин А.И., Порядин Г.В. Патологическая физиология. - М.: Медпресс, 2000. - 340 с.

2. Григорьян А.С., Морфогенез ранних стадий воспаления заболеваний пародонта / А.С. Григорьян, О.А. Фролова, Е.В. Иванова //Стоматология. - 2002. - N1. - С. 19-25.

3. Пахомов, Г.Н. О прошлом, настоящем и будущем стоматологии / Г.Н. Пахомов // Новое в стоматологии. - 2002. N6. - C. 5-8.

4. Цепов, Л.М., Диагностика и лечение заболеваний пародонта / Л.М. Цепов, А.И. Николаев. М.: «МЕДпресс-

информ». - 2004. - 200c

5. Kinane, D.F. Clinical relevance of the host resposes of periodontitis / D.F. Kinane, P. Mark Bartild // Periodontal. 2000. 2007. Vol. 43. P. 278-293.

6. Nunn, M.E. Understanding the etiology of periodontitis: an overview of periodontal risk factors / M.E. Nunn // Periodontol 2000. - 2003. Vol. 32. P. 11-23.

7. Socransky, S.S. Subgingival microbial profiles in refractory periodontal disease / S.S. Socransky, C. Smith, A.D. Haffajee // Clin. Periodontol. - 2002. Vol. 29. P. 260-268.

\section{REFERENCES}

1. Volozhin A.I., Poryadin G.V. Pathological physiology. - M .: Medpress, 2000. - P. 340.

2. Grigoryan A.S., Morphogenesis of early stages of inflammation of periodontal diseases / A.S. Grigoryan, O.A. Frolova, E.V. Ivanova // Stomatology. - 2002. - N1. - P. 19-25.

3. Pakhomov, G.N. About the past, present and future of dentistry / G.N. Pakhomov // New in dentistry. - 2002. - N6. - P. 5 8.

4. Tsepov L.M., Diagnosis and treatment of periodontal diseases / L.M. Tsepov, A.I. Nikolaev. M .: " MEDpress-inform ". -

2004. -P. - 200.

5. Kinane, D.F. Clinical relevance of the host resposes of periodontitis / D.F. Kinane, P. Mark Bartild // Periodontal. 2000. 2007. Vol. 43. P. 278-293.

6. Nunn, M.E. Understanding the etiology of periodontitis: an overview of periodontal risk factors / M.E. Nunn // Periodontol 2000. - 2003. Vol. 32. P. 11-23.

7. Socransky, S.S. Subgingival microbial profiles in refractory periodontal disease / S.S. Socransky, C. Smith, A.D. Haffajee // Clin. Periodontol. - 2002. Vol. 29. P. 260-268. 